\title{
Molecular mechanisms of long noncoding RNAs and their role in disease pathogenesis
}

\author{
Guoku Hu${ }^{1}$, Fang Niu${ }^{1}$, Bree A. Humburg ${ }^{1}$, Ke Liao $^{1}$, Sunil Bendi ${ }^{1}$, Shannon Callen ${ }^{1}$, \\ Howard S. Fox ${ }^{1}$ and Shilpa Buch ${ }^{1}$ \\ ${ }^{1}$ Department of Pharmacology and Experimental Neuroscience, University of Nebraska Medical Center, Omaha, NE, USA \\ Correspondence to: Shilpa Buch, email: sbuch@unmc.edu \\ Guoku Hu, email: guoku.hu@unmc.edu
}

Keywords: long non-coding RNA; CNS disorder; cancer; therapy

Received: December 07, $2017 \quad$ Accepted: January 13, $2018 \quad$ Published: April 06, 2018

Copyright: Hu et al. This is an open-access article distributed under the terms of the Creative Commons Attribution License 3.0 (CC BY 3.0), which permits unrestricted use, distribution, and reproduction in any medium, provided the original author and source are credited.

\section{ABSTRACT}

LncRNAs are long non-coding regulatory RNAs that are longer than 200 nucleotides. One of the major functions of IncRNAs is the regulation of specific gene expression at multiple steps including, recruitment and expression of basal transcription machinery, post-transcriptional modifications and epigenetics [1]. Emerging evidence suggests that IncRNAs also play a critical role in maintaining tissue homeostasis during physiological and pathological conditions, lipid homeostasis, as well as epithelial and smooth muscle cell homeostasis, a topic that has been elegantly reviewed [2-5]. While aberrant expression of IncRNAs has been implicated in several disease conditions, there is paucity of information about their contribution to the etiology of diseases [6]. Several studies have compared the expression of IncRNAs under normal and cancerous conditions and found differential expression of several IncRNAs, suggesting thereby an involvement of IncRNAs in disease processes [7, 8]. Furthermore, the ability of IncRNAs to influence epigenetic changes also underlies their role in disease pathogenesis since epigenetic regulation is known to play a critical role in many human diseases [1]. LncRNAs thus are not only involved in homeostatic functioning but also play a vital role in the progression of many diseases, thereby underscoring their potential as novel therapeutic targets for the alleviation of a variety of human disease conditions.

\section{INTRODUCTION}

Long non-coding RNAs (lncRNAs) are a large and diverse class of transcribed RNA molecules that lack many signature motifs of mRNAs, including the Kozak consensus sequence $[9,10]$ and open reading frame (ORF) of significant lengths [11]. To date it has been estimated that the human genome contains approximately 51,382 lncRNA genes [12], 20,000-25,000 protein-coding genes [13] and about 2,500 miRNAs [14]. Many of lncRNAs show spatial-temporal and tissue-specific patterns of expression, suggesting thereby that the expression of lncRNAs is programmed and highly regulated during both development as well as pathogenesis. One clue has been their responsiveness to well-characterized transcription factors. In 2003 Martone et al. reported the presence of NF- $\mathrm{BB}$-binding sites distributed across the human genome in both coding as well as noncoding regions, thereby suggesting that in addition to mRNA, non-coding RNAs may also be regulated by NF- $\kappa B$ [15]. Indeed, data from Lander's group have shown that lncRNAs are transcriptionally regulated by key transcription factors such as p53, NF- $\kappa$ B, Sox2, Oct4 and Nanog under various external stimuli [16]. For example, in this particular study the authors exposed mouse embryonic fibroblasts (MEF; p53+/+ and p53-/-) to a DNA damaging agent and profiled the cells for changes in lncRNA expression by microarray. Their findings identified 39 lncRNAs that were significantly increased in p53+/+ but not in p53-/- cells. Furthermore, the promoters of these 
upregulated lncRNAs were found to be enriched for the p53 cis-regulatory binding element. These findings thus implicated the role of p53 in transcriptional regulation of lnRNA via direct binding of the transcription factor to the lnRNA promoter. These authors also explored the role of the TLR4/NF- $\kappa \mathrm{B}$ signaling pathway in the transcriptional regulation of IncRNA by stimulating $\mathrm{CD} 11 \mathrm{c}+$ bonemarrow-derived dendritic cells with a specific agonist of TLR4. Herein they found marked upregulation of twenty lncRNAs following stimulation including lincRNA-Cox 2 that exhibited $\sim 1000$-fold increase. Subsequent studies have further demonstrated that NF- $\mathrm{BB}$-induced lincRNACox 2 also serves as a coactivator of transcriptional factors regulating the expression of a vast array of immune related genes in macrophages, microglia and epithelial cells $[17,18]$. In another report, in loss-of-function studies using the pluripotency-associated transcription factors, it was also shown that IncRNA genes were regulated by key transcription factors. In addition, lncRNA expression was also affected in response to many external stimuli. For example, lncRNA $B A C E 1-A S$, the BACE1-antisense transcript, is upregulated by various cell stressors, such as high temperature, serum, starvation, $A \beta 1-42$ (beta-amyloid 42), hydrogen peroxide $\left(\mathrm{H}_{2} \mathrm{O}_{2}\right)$ or high glucose [19]. Observations from different groups have demonstrated that lncRNA Sat III RNAs are also induced by a wide range of stressors including DNA damaging agents, oxidative stress, hypoxia, hyper-osmotic stress and heavy metals $[20,21]$. Additionally, in various tumor cell lines and following DNA damage, induced p53 can bind to the promoter of $\ln c R N A-p 21$, a transcriptional target of $\mathrm{p} 53$, leading, in turn, to enhanced expression of the $\operatorname{lnc} R N A-p 21$. Taken together, there is ample evidence demonstrating that similar to mRNA, lncRNA transcription is also under strict regulation by various cellular pathways.

\section{MOLECULAR MECHANISM(S) UNDERLYING LNCRNA ACTION}

Though little is known about the three-dimensional structures of lncRNAs, it is becoming clear that lncRNAs interact with other molecules, such as proteins, DNA, RNA and metal ions, to form proper tertiary structure to exert their functions. The underlying molecular mechanisms by which lncRNAs affect various biological processes, including chromatin organization, epigenetic regulation, gene transcription and translation, RNA turnover and genome defense, have been reviewed extensively [1, 22-25]. Herein we categorize the mechanisms of lncRNA action into five archetypes based on their interaction partners and direct effects (Figure 1).

\section{Protein-IncRNA}

Unlike miRNAs, lncRNAs are able to display complex secondary and tertiary structures which provide multiple binding sites for other molecules. It is well known that lncRNAs can serve as structural scaffolds to build protein complexes. An excellent example is HOTAIR lncRNA that has two arms, each of which binds to a distinct protein, PRC2 and LSD1/coREST/REST, and acts as a scaffold to coordinate the recruitment of protein complexes onto chromatin [26]. The 5' $300 \mathrm{nt}$ of the HOTAIR lncRNA binds to PRC2 while the 3' 700 nt region interacts with the LSD1/coREST/REST complexes which, in turn, methylates histone H3 at K27 and demethylates histone $\mathrm{H} 3$ at $\mathrm{K} 4$ to repress gene transcription [26, 27]. Similarly, ANRIL, a $3.8 \mathrm{~kb}$-antisense lncRNA, can directly interact with components from both PRC1 and $\mathrm{PRC} 2$ complexes and regulate the expression of proteincoding genes in a cis manner at the level of chromatin modification [28, 29]. Interestingly, Xist, a 17-kb lncRNA, can also recruit PRC1 and PRC2 to the chromatin [30, 31]. These observations have led to queries over whether lncRNAs interact with each other within the same complex to form a higher order structure and function jointly, and/ or whether the lncRNAs play a distinct role in various physiological and pathological conditions. Work in this area warrants further investigations.

\section{IncRNA-DNA}

LncRNAs can also directly bind to genomic DNA elements, such as the gene promoters and regulate gene transcription. In fact, it has been shown that a subset of lncRNAs do contain $5^{\prime}$ boundaries of the protein-coding genes but not complete exons. These lncRNAs are also termed as promoter-associated IRNAs (PALRs) [32]. An elegant study by Blume et al. demonstrated a nucleus enriched lncRNA, dhfr minor transcript, transcribed from the upstream minor promoter of the dihydrofolate reductase $(D H F R)$ gene [33-35]. Furthermore, it was also shown that the $d h f r$ minor transcript functions as a regulatory molecule to modulate the transcriptional activity of the $d h f r$ core promoter [33]. A subsequent study by Martianov and coworkers demonstrated that this lncRNA mediated the formation of a stable RNADNA triplex structure within the major promoter of DHFR gene that prevented the binding of the general transcription factor TFIIB, thereby leading to repression of the DHFR gene expression [36]. A standard H-form band-shift assay further demonstrated that the formation of the lncRNA-DNA complex yielded a highly specific and stable triplex structure [36]. In addition to RNA-DNA triplex structure, lncRNAs can also form duplexes with DNA elements and establish complex configurations based on sequence complementarity [37]. For example, lncRNA ANRASSF1 (antisense noncoding of RASSF1) recruits PRC2 to the RASSF 1A promoter region, where both the lncRNA and the host gene are transcribed in a highly location-specific manner leading, in turn, to repression of RASSF1A transcription [38]. The direct interaction 
between $A N R A S S F 1$ and promoter was also evidenced by a reduced level of $A N R A S S F 1$ in cell lysis treated with RNase H, that digests RNA/DNA hybrids [38]. Further research is needed to understand: a) the multitude of components comprising the lncRNA/DNA complex, b) whether lncRNAs exert their function at the local genome loci during or subsequent to their production and, c) the fate of these lncRNAs.

\section{IncRNA-RNA}

Within the nucleic acid structure of lncRNAs lies their inherent ability to bind to other RNAs, such as mRNAs and miRNAs, with either imperfect or perfect complementarity. By directly interacting with mRNAs, lncRNAs play a key role in the regulation of mRNA splicing, editing, subcellular distribution and stability [37, 39]. For example, $\mathrm{Hu}$ and coworkers demonstrated that lncRNA 5S-OT (transcribed from $5 \mathrm{~S}$ rDNA loci) modulates alternative splicing of a subset of mRNAs in trans via RNA-RNA pairing and by interacting with the splicing factor U2AF65 [39]. Interestingly, $5 S$ OT knockdown resulted in altered splicing of about 174 and 173 genes in both undifferentiated and differentiating THP-1 cells, respectively, leading in turn, to decreased differentiation efficiency of THP-1 cells [39]. Additionally, it was shown by Johnsson et al. that the PTEN pseudogene expressed a noncoding RNA, PTENpg1, which serves as a miRNA sponge, can interact with $\beta$ isoform of its antisense RNA through RNA-RNA pairing. This interaction leads to increased sponge activity of PTENpgl sense miRNA thereby resulting in increased PTEN mRNA stability and translation [40]. Furthermore, it has been shown that lncRNA EWSAT1 (Ewing sarcoma associated transcript 1) acts as a reservoir of miR-326/330-5p [41]. Highly expressed EWSAT1 in human nasopharyngeal carcinoma tissues and cell lines increases the expression of miR$326 / 330-5 p$ clusters that target the gene cyclin D1, ultimately regulating NPC development and progression [41]. Although several IncRNA-miRNA-mRNA networks have been identified in recent years [42, 43], the underlying mechanism(s) by which miRNA competes with binding either lncRNA or mRNA still remains unclear.

\section{Peptide-coding}

Although by definition, lncRNAs generally lack protein-coding capacity, however, recent studies have demonstrated that a small fraction of lncRNAs with short open reading frames (ORFs) actually codes for peptides with biological functions [44-48]. For example, it was shown by Anderson and colleagues that a putative lncRNA, myoregulin $(M L N)$, contains a short ORF encoding a conserved 46 amino acid peptide [45]. The human and mouse $M L N$ genes comprising of three exons span the genomic regions of 16.5 and $15.0 \mathrm{~kb}$, respectively. Biochemical and animal studies have indicated that $M L N$ forms a single transmembrane alpha helix and interacts with $M L N$ in the membrane of the SR (sarcoplasmic reticulum) and plays a role in regulating $\mathrm{SR} \mathrm{Ca}^{2+}$ levels by inhibiting SERCA pump activity. Strikingly, $M L N$ KO

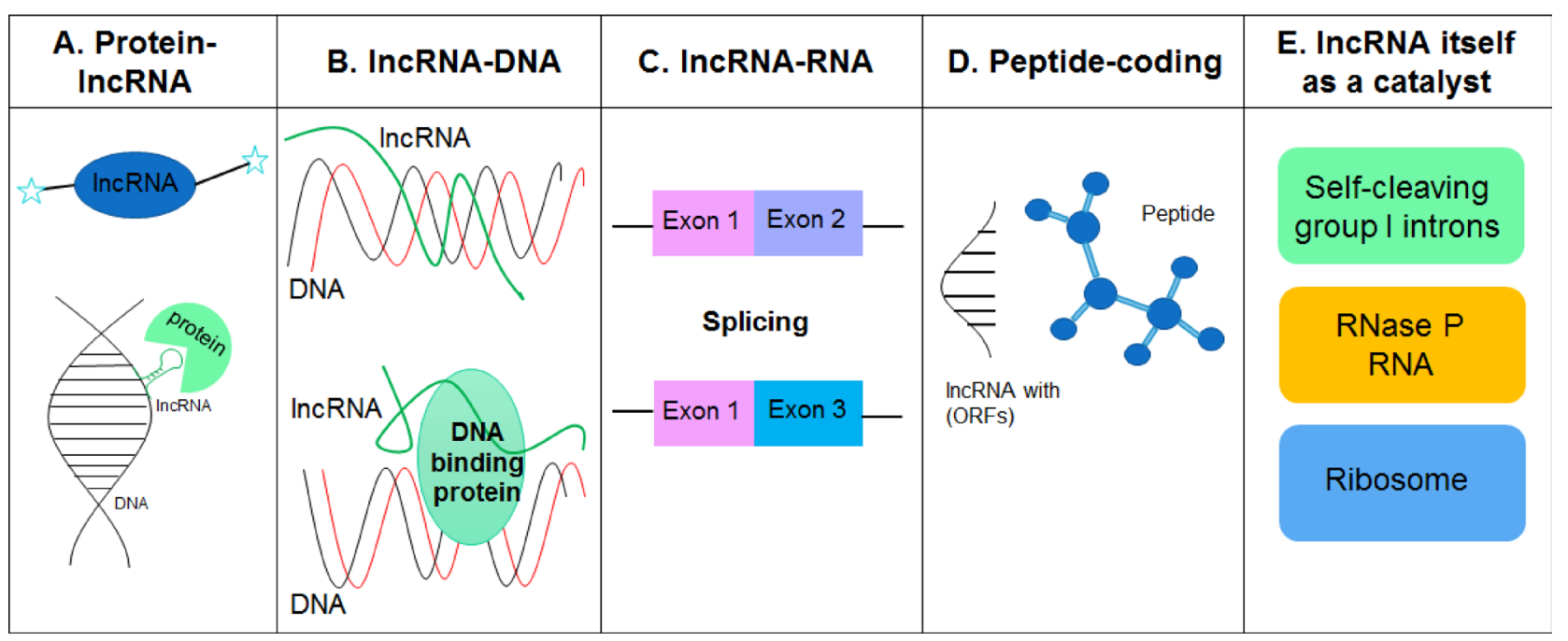

Figure 1: LncRNAs interact with other molecules such as proteins, DNA, RNA and metal ions to form proper tertiary structures (RNA is negatively charged) and exert their functions. (A) LncRNAs can display complex secondary and tertiary structures that offer multiple binding sites for other molecules. (B) LncRNAs can bind to genomic DNA elements, such as gene promoter regions, and regulate gene transcription. (C) LncRNAs can bind to other RNAs and are involved in the regulation of mRNA splicing, editing, subcellular distribution and stability. (D) LncRNAs with short open reading frames (ORFs) code peptides. Both mRNAs and lncRNAs play dual roles as protein/peptide-coding and non-coding RNAs. (E) Catalytic RNAs (ribozyme) such as self-cleaving group 1 introns, RNase P RNA, and the ribosome, play an important role in various biological processes including RNA processing and protein synthesis. 
mice demonstrated significantly increased $\mathrm{SR} \mathrm{Ca}^{2+}$ levels in myoblasts with enhanced skeletal muscle performance compared to WT mice, indicating thereby that $M L N$ plays an important role in adult skeletal muscle functioning [45]. Similarly, lncRNA DWORF (dwarf open reading frame) encodes a 34 amino acid peptide that localizes to the SR membrane [46]. In animal studies, it was shown that DWORF overexpression increased the peak systolic $\mathrm{Ca}^{2+}$ transient amplitude as well as $\mathrm{SR} \mathrm{Ca}^{2+}$ load and that, conversely, Dworf KO mice showed decreased affinity of SERCA for $\mathrm{Ca}^{2+}$ with delayed $\mathrm{Ca}^{2+}$ clearance and relaxation [46]. Another lncRNA with a protein coding capacity is LINC00961 that has been identified as a repressor of $\mathrm{mTORC} 1$ activation, via its interaction with the lysosomal v-ATPase in the late endosome/lysosome [44]. LINC00961 is highly expressed in the lung, heart and skeletal muscle and yields a 90 amino acid polypeptide. Interestingly, in animal studies it was demonstrated that loss of this polypeptide promoted muscle regeneration following injury [44]. These studies thus underscore the fact that peptides encoded by lncRNAs play a key role in the maintenance of muscle homeostasis. It is thus speculated that both mRNAs and lncRNAs can play dual roles as either protein/peptide-coding as well as non-coding RNAs.

\section{IncRNA as a catalytic RNA}

Catalytic RNAs (known as ribozymes) are RNA molecules that have catalytic enzyme activity. Catalytic RNAs, such as the self-cleaving group I introns [49], the RNase P RNA [50, 51] and the ribosome [52], play a role in various biological processes, including RNA processing and protein synthesis. Given that secondary and tertiary structures are important for their function and regulation of catalytic RNAs, such as ribosomal RNA (rRNA) and transfer RNA (tRNA), and the experimental difficulties in measuring RNA structure, computational approaches for predicting RNA structure from primary sequence have been developed and used in various studies. Experimentally, nucleotide analog interference mapping (NAIM) is an efficient and a powerful approach to study RNA substructures and functional groups at the atomic level. This method has been applied to identify many catalytic RNAs, such as the Hepatitis Delta Virus (HDV), the hairpin and the Varkud Satellite (VS) ribozymes [53]. Thus, within the lncRNA community efforts aimed at combining computational and experimental approaches to reveal the catalytic functions of lncRNAs and their underlying mechanisms are gaining a lot of momentum.

In summary, lncRNAs participate in the regulation of gene expression at many levels, including epigenetic, transcriptional, RNA splicing, nuclear shuttling, posttranscriptional, translational and post-translational, and are mediated by various underlying mechanisms.

\section{LNCRNAS IN HUMAN DISEASES}

The role of lncRNAs in the regulation of cellular processes and disease progression is gaining attention. While lncRNAs are known to play pivotal roles in maintaining cellular and organismal homeostasis, dysregulation of their expression during the onset and development of various diseases has often been implicated in the regulation of a wide array of genes including those involved in metabolism, cell death, angiogenesis and metastasis. LncRNA-mediated regulation of disease pathogenesis (Table 1) thus represents an evolving area of research that has ramifications for the identification of potential therapeutic targets for various diseases, including cancers and neurodegenerative disorders, for which, currently there exists no cure. Several elegant reviews have recently highlighted and described the role of lncRNAs in colorectal cancer $[54,55]$, prostate cancer [56-58] and rheumatic diseases [59]. Herein, we briefly summarize the latest findings on the role of lncRNAs in breast cancer, bladder cancer, cardiovascular and CNS diseases.

\section{Role of IncRNAs in breast cancer}

The lifetime risk of breast cancer is about 1 in 8 for all women with $11 \%$ mortality from the disease within five years of diagnosis. Since the presence of hormone receptors, such as the estrogen receptor (ER), progesterone receptor (PR) and human epidermal receptor 2 (HER2) are critical for cancer cell growth, these receptors are often used for diagnosis and as therapeutic targets to treatment of breast cancer.

The earliest identified and most extensively studied cancer-related lncRNAs include H19, XIST and MALAT1. H19 was first identified as imprinted fetal lncRNA that was highly expressed in ER+ breast tumors and cell lines. Interestingly, H19 was also increased in paclitaxel (PTX, often used post-surgery to kill remaining cancer cells) resistant ER+ breast cancer cells. $H 19$ promotes proliferation and attenuates apoptosis in breast cancer cells, implicating its role in tumorigenesis and tumor growth [60-64]. In contrast, XIST is a downregulated IncRNA found in breast tumor samples and other cancer cell lines that acts as a tumor suppressor. Loss- and gain-of-function studies demonstrated that XIST negatively regulates breast cancer cell viability through suppression of AKT signaling. MALAT1 is significantly upregulated in breast cancer, especially in ER+ and HER2+ tumors, and MALAT1 is required for breast cell proliferation, migration and invasion, as knockdown of MALAT1 results in slower tumor growth and a reduction in metastasis, indicating its role in cancer development and progression [65-69].

To comprehensively identify breast cancerassociated lncRNAs, Niknafs and co-workers investigated 
Table 1: LncRNA-mediated regulation of disease pathogenesis

\begin{tabular}{|c|c|c|c|c|c|}
\hline Disease & LncRNAs & Target & Role of LncRNAs & Model & Reference \\
\hline \multirow[t]{6}{*}{$\begin{array}{l}\text { Alzheimer's } \\
\text { Disease (AD) }\end{array}$} & UP: BACE $1-\mathrm{AS}$ & UP: BACE1 & $\begin{array}{l}\text { Increase BACE1 mRNA stability } \\
\text { and generate additional A } \beta 1-42\end{array}$ & $\begin{array}{c}\text { Amyloid precursor protein } \\
\text { transgenic mice, BACE1-AS } \\
\text { Knock down in Tg } 19959 \text { mouse }\end{array}$ & {$[19,100]$} \\
\hline & UP: 51A & $\begin{array}{l}\text { Down: SORL1 } \\
\text { variant A }\end{array}$ & $\begin{array}{l}\text { Impaired processing of APP and } \\
\text { increased } A \beta \text { formation }\end{array}$ & $\begin{array}{l}\text { Frontal and temporal cortices } \\
\text { from AD and control cases, } \\
\text { Neuroblastoma cell lines } \\
\text { (SKNBE2 and SHSY5Y) }\end{array}$ & [101] \\
\hline & Up: 17A & $\begin{array}{l}\text { Abolish GABA } \\
\text { B2 intracellular } \\
\quad \text { signaling }\end{array}$ & $\begin{array}{c}\text { Enhances } A \beta \text { secretion and } A \beta \\
x-42 / A \beta x-40 \text { ratio }\end{array}$ & $\begin{array}{l}\text { Frontal and temporal cortices } \\
\text { from } \mathrm{AD} \text { and control cases, } \\
\text { neuroblastoma cells }\end{array}$ & {$[145]$} \\
\hline & Up: NDM29 & $\begin{array}{l}\text { Induce APP } \\
\text { synthesis }\end{array}$ & $\begin{array}{c}\text { Enhances } A \beta \text { secretion and } A \beta \\
x-42 / A \beta x-40 \text { ratio }\end{array}$ & $\begin{array}{l}\text { Frontal and temporal cortices } \\
\text { from } \mathrm{AD} \text { and control cases, } \\
\text { neuroblastoma cells }\end{array}$ & {$[146]$} \\
\hline & Up: BC200 & Inhibit eIF4A & $\begin{array}{c}\text { Repress local translation in } \\
\text { synapses }\end{array}$ & $\begin{array}{l}\text { Brodmann's area } 9 \text { in AD and } \\
\text { different ages of human cases }\end{array}$ & {$[107]$} \\
\hline & Up: NAT-Rad18 & RAD18 & $\begin{array}{c}\text { Cause Neuron more sensitive to } \\
\text { apoptosis }\end{array}$ & $\begin{array}{l}\text { beta-amyloid (Abeta) exposed } \\
\text { protein rat cortical neurons }\end{array}$ & {$[147,148]$} \\
\hline \multirow[t]{3}{*}{$\begin{array}{l}\text { Huntington } \\
\text { Disease (HD) }\end{array}$} & $\begin{array}{l}\text { Down: HAR1F } \\
\text { Down: HAR1R }\end{array}$ & & $\begin{array}{l}\text { associated with human-specific } \\
\text { brain development and function, } \\
\text { repressed by REST in HD }\end{array}$ & $\begin{array}{l}\text { Normal and HD subjects' cortex } \\
\text { (Brodman Area 7,9) and striatum }\end{array}$ & {$[118]$} \\
\hline & Down: ABHD11OS & $\begin{array}{l}\text { N-terminal } \\
\text { fragment of mutant } \\
\text { huntingtin }\end{array}$ & Product neuroprotection & BACHD Tg and KI140 mouse & {$[120]$} \\
\hline & Down: TUNA & $\begin{array}{l}\text { TUNA-RBP } \\
\text { complex }\end{array}$ & $\begin{array}{l}\text { Inhibits neural differentiation of } \\
\text { mESCs }\end{array}$ & $\begin{array}{c}\text { mouse embryonic stem cells, } \\
\text { zebrafish }\end{array}$ & {$[119]$} \\
\hline \multirow[t]{3}{*}{$\begin{array}{l}\text { Parkinson } \\
\text { disease (PD) }\end{array}$} & $\begin{array}{l}\text { PINK } 1-A S \text { (naPINK } \\
1 \text { ) }\end{array}$ & PINK1 & $\begin{array}{l}\text { Impairment of mitochondrial } \\
\text { dynamics due to decrease in the } \\
\text { PINK1-AS and neurodegeneration } \\
\text { due to ASUCHL1 downregulation }\end{array}$ & $\begin{array}{c}\text { Human muscle biopsy samples, } \\
\text { neuronal cell lines }\end{array}$ & {$[127]$} \\
\hline & UP: HOTAIR & LRRK2 & $\begin{array}{l}\text { Promote Parkinson's Disease } \\
\text { induced by MPTP }\end{array}$ & $\begin{array}{l}\text { Neurochemical mouse model of } \\
\text { PD }\end{array}$ & {$[149]$} \\
\hline & Down: AS Uch1 & Uchl1 & $\begin{array}{c}\text { Controlled by Nurr1, a transcription } \\
\text { factor required for DA cells } \\
\text { differentiation }\end{array}$ & $\begin{array}{l}\text { Murine dopaminergic MN9D } \\
\text { cells, Neurochemical mouse } \\
\text { model of PD }\end{array}$ & {$[131]$} \\
\hline \multirow[t]{5}{*}{$\begin{array}{l}\text { Cardio } \\
\text { Vascular } \\
\text { disease } \\
(\text { CVD) }\end{array}$} & CHAER & $\begin{array}{l}\text { Catalytic subunit } \\
\text { of polycomb } \\
\text { repressor complex } \\
\quad 2 \text { (PRC2) }\end{array}$ & $\begin{array}{c}\text { Gene induction and hypertrophy of } \\
\text { cardiac muscles }\end{array}$ & CHAER knock out mouse model & {$[98]$} \\
\hline & Up: MALAT1 & $\operatorname{miR} 133$ & $\begin{array}{l}\text { increase levels of serum response } \\
\text { factor (SRF) }\end{array}$ & $\alpha$-MHC-SRF transgenic mouse & $\begin{array}{l}{[150]} \\
{[151]}\end{array}$ \\
\hline & Up: KCNQ1OT1 & KCNQ1 & $\begin{array}{l}\text { Affects chromatin conformation } \\
\text { and expression of Kcnq1 }\end{array}$ & K-term mouse & {$[150,152]$} \\
\hline & Down: Novlnc6 & $\begin{array}{l}\text { Bmp10 and } \\
\text { Nkx2.5 }\end{array}$ & $\begin{array}{l}\text { Involved in cardiogenesis, also } \\
\text { have essential functions in the } \\
\text { progression of acute myocardial } \\
\text { infarction }\end{array}$ & $\begin{array}{c}\text { Plasma from CAD patients, } \\
\text { VSMCs }\end{array}$ & {$[153,154]$} \\
\hline & Down: Mhrt & Brg1 & $\begin{array}{c}\text { cardiac hypertrophy and subsequent } \\
\text { heart failure }\end{array}$ & $\begin{array}{l}\text { Tnnt2-rtTA, Tre-Mhrt779 (Tg779) } \\
\text { mice, human heart tissue }\end{array}$ & {$[97]$} \\
\hline \multirow[t]{3}{*}{ Breast cancer } & Up: H19 & $\begin{array}{l}\mathrm{miR}-200 \mathrm{~b} / \mathrm{c} \text { and } \\
\text { let- } 7 \mathrm{~b}\end{array}$ & Regulates the metastasis & $\begin{array}{l}\text { DSCAM-AS1 knock down in } \\
\text { luminal breast cancer cell lines }\end{array}$ & [155] \\
\hline & Down: XIST & $\mathrm{AKT}$ & $\begin{array}{l}\text { XIST negatively regulates cell } \\
\text { viability via inhibition of AKT } \\
\text { activation }\end{array}$ & Breast cancer cell line & {$[156]$} \\
\hline & Up: MALAT1 & $\begin{array}{l}\text { Interacts with } \\
\text { estrogen receptor, } \\
\text { serine/arginine } \\
\text { splicing factors }\end{array}$ & $\begin{array}{l}\text { regulate process of cancer cell } \\
\text { migration, cell cycle progression } \\
\text { and alternative splicing }\end{array}$ & $\begin{array}{l}\text { Breast cancer cell lines, non- } \\
\text { metastatic breast tumors patients, } \\
\text { MMTV-PyMT Malat1+/+; } \\
\text { MMTV-PyMT Malat1+/-; } \\
\text { MMTV-PyMT Malat1-/- mice }\end{array}$ & $\begin{array}{c}{[92,157,} \\
158]\end{array}$ \\
\hline
\end{tabular}




\begin{tabular}{cccccc} 
& Up: DSCAM-AS1 & hnRNPL & $\begin{array}{c}\text { mediates tumour progression and } \\
\text { tamoxifen resistance }\end{array}$ & $\begin{array}{c}\text { T47D, ZR75-1, MCF7 cells; } \\
\text { human breast cancer }\end{array}$ & [70] \\
$\begin{array}{l}\text { Bladder } \\
\text { cancer }\end{array}$ & Down: TUG1 & HMGB1 & $\begin{array}{c}\text { Potential regulator of } \\
\text { radioresistence of bladder cancer }\end{array}$ & siRNA knock down of TUG1 & [159] \\
& Up: UCA1 & Hexokinase 2 & Promotes glycolysis & human bladder cancer cell lines & [160] \\
\hline
\end{tabular}

IncRNA expression profiles from 947 breast tumor RNAseq samples and demonstrated that almost 437 of the lncRNAs were differentially expressed in breast cancer [70]. Among these, 63 lncRNAs were upregulated in both breast cancer cells compared with normal and $\mathrm{ER}+$ compared with ER- tumors, including DSCAM$A S 1$. Indeed, $D S C A M-A S 1$ is a cancer specific lncRNA that is highly expressed in ER+ cells, and is involved in the proliferation of luminal breast cancer cell lines [71]. DSCAM-AS1 knockdown reduced the proliferative ability of breast cancer cell lines while DSCAM-AS1 overexpression enhanced proliferation of ER+ breast cancer cell lines [70]. Importantly, in tamoxifen-resistant cells, the expression of DSCAM-AS1 was further upregulated, despite reduced expression of canonical ER targets (GREB1 and PGR) compared to the parental cells. Furthermore, knockdown of DSCAM-AS1 in these tamoxifen-resistant cells reduced the proliferation rate to the level of parental MCF7 cells, suggesting a role of DSCAM-AS1 in tumor progression and tamoxifen resistance in ER+ breast cancer [70, 71].

Recently, another comprehensive analysis was performed by Van Grembergen and colleagues to explore the lncRNA landscape across 995 breast tissue samples [72]. Using Affymetrix Human Genome U133 Plus 2.0 array data from 823 breast tumors and 172 normal breast tissues, 215 lncRNAs were identified as dysregulated in at least $10 \%$ of the breast tumors. In terms of function, these lncRNAs were found to underlie various molecular processes, including the EGFR, PI3K, MAPK and E2F1 pathways. Specifically, a set of lncRNAs were differentially expressed in ER+ and ER- breast tumors, including well-known ones such as NEAT1, MALAT1 and Xist, and also novel lncRNAs LINC01297 and RP11-303E16.2. Of note, lncRNA-CYTOR (cytoskeleton regulator, also known as LINC00152) was up-regulated in all subtypes of breast cancer and was found to functionally regulate cell proliferation, migration and cytoskeleton organization [72]. The role of lncRNAs in breast cancer has recently been insightfully reviewed by Soudyab et al. [73] and by Warburton and Boone [74].

\section{Role of IncRNAs in bladder cancer}

Bladder cancer usually arises from the epithelial cell lining of the bladder. Cystoscopy is a gold standard for diagnosing bladder cancer, albeit it often comes with the risk of infection or injury to the bladder. Detection of genetic aberrations with fluorescent in situ hybridization in the cells that are shed in urine is a widely-used non- invasive method for the diagnosis of bladder cancer; however, it is more expensive than cystoscopy and has lower sensitivity and specificity. There is therefore an urgent need to identify novel biomarkers for early detection and routine screening for bladder cancer. Emerging evidence demonstrates that lncRNAs play a pivotal role in bladder cancer initiation, development and metastasis, thereby underpinning their potential roles as novel indicators of bladder cancer as well as therapeutic targets. To date, many aberrantly expressed lncRNAs have been identified in bladder cancer, including upregulated lncRNAs, H19, MALAT1, SNHG16, TUG1, UCA1, TINCR and Linc-UBC1; and downregulated lncRNAs, $B A N C R$ and MEG3 [75-78]. H19 was the first lncRNA to be associated with bladder cancer [79] and its expression is significantly increased in bladder cancer tissue versus the adjacent normal control tissue [80, 81]. Further studies demonstrated that upregulated $H 19$ promoted proliferation and metastasis of bladder cancer cells via upregulation of inhibitor of DNA binding/differentiation 2 (ID2) and downregulation of E-cadherin [81, 82]. Urothelial cancer associated 1 (UCA1) lncRNA is highly expressed in bladder tumor tissues [83-85] and has been used to distinguish bladder cancer from other urinary related diseases [86]. Both in vitro and in vivo studies demonstrated that overexpression of UCA1 increased proliferation, migration, invasion and chemoresistance of bladder cells; antagonized cell apoptosis induced by cisplatin and promoted tumorigenicity of human bladder carcinoma cells $[87,88]$. Recent studies have suggested that CCAAT/enhancer binding protein alpha $(\mathrm{C} / \mathrm{EBP}$ alpha) positively regulates $U C A 1$ expression. Upregulated $U C A 1$ resulted in increased Wnt signaling and enhanced ERK1/2 MAPK and PI3-K/AKT kinase activity and p300 expression which, in turn, regulated gene transcription via chromatin remodeling that resulted in cell cycle progression, carcinogenesis and cancer invasion [89, 90]. In addition, TUG1 is another lncRNA that was significantly increased in bladder cancer and was associated with reduced overall survival of bladder cancer patients [91]. Results from in vitro studies demonstrated that knockdown of TUG1 by siRNA significantly decreased proliferation and migration of bladder cancer cells [91], implicating thereby that IncRNAs could also be envisioned as potential therapeutic targets for preventing cancer invasion and metastasis.

Though there is no evidence supporting the fact that any single lncRNA could serve as a reliable biomarker for cancer, multiple lncRNAs (together as a panel) could be used for cancer diagnosis at various stages, especially, 
given that distinct lncRNAs could be dysregulated by various risk factors leading to oncogenesis (Figure 2).

\section{Role of IncRNAs in cardiovascular disease (CVD)}

Cardiovascular disease (CVD) is a pathological spectrum involving dysfunction of the heart and/ or blood vessels. Many risk factors have been identified for CVDs, including age, gender, diet, environment and genetics. Among these, genetic factors play a major role in the development of CVDs. Given that $98 \%$ of the human genome is transcribed into lncRNAs [92-94], it is not surprising that lncRNAs are involved in cardiac development and disease. For example, in a pressureoverload-induced heart failure mouse model, Lee and colleagues demonstrated that almost 150 out of the 700 assessed lncRNAs were differentially expressed during various stages of heart failure [95]. Importantly, Yang et al. detected 18,480 lncRNAs in the human left ventricle using RNA sequencing. Out of these, about 1,249 lncRNAs were differentially expressed in heart failure [96]. Further analyses implicate that cardiac lncRNAs could act through cis mechanisms in mediating the pathogenesis of heart failure [96].

In another study performed by Han and colleagues, a cluster of lncRNAs transcribed from the Myh7 loci designated as myosin heavy-chain-associated RNA transcripts (Myheart, or Mhrt) [97], was identified in mice. Interestingly, these IncRNAs that are cardiac-specific with high abundance in the adult heart were found to be repressed in various types of cardiac myopathies. In this study, the authors demonstrated that overexpression of Mhrt resulted in reduced hypertrophy with improved fractional shortening in transaortic constricted (TAC) mice. The cardioprotective effects of Mhrt suggested a potential role of IncRNAs as therapeutics for CVDs. A subsequent study identified another heart-enriched lncRNA, cardiachypertrophy-associated epigenetic regulator (Chaer), that is required for the development of cardiac hypertrophy [98] and that has been shown to play a role in regulating cardiomyocte gene expression in both rodents and humans [98]. It must be noted that most of the findings on cardiac IncRNAs have been reported in either cell culture or in animal models with scant information in humans. Understanding how these animal studies translate into the human context is an urgent need in the field.

\section{Role of IncRNAs in Alzheimer's disease (AD)}

Alzheimer's disease (AD) is the most common cause of dementia (a group of brain disorders) often manifesting in late life, that is clinically characterized by loss of intellectual and social skills. The AD brain shows increased accumulation of extraneuronal amyloid beta $(A \beta)$ plaques and intraneuronal aggregation of hyperphosphorylated tau in neurofibrillary tangles with various other accompanying pathological features such as microglial activation and neuronal degeneration. $A \beta$ is generated from sequential cleavage of amyloid precursor protein (APP) by $\beta$-site APP-cleaving enzyme 1 (BACE). LncRNA, BACE1-AS, an antisense transcript of $B A C E$, has been shown to be increased in the human AD brains compared with the matched controls [19]. RTPCR analysis demonstrated that $B A C E 1-A S$ transcripts are two to three times more abundant in glial cells (M059K), a major source of $\mathrm{A} \beta$ production in the brain [99], compared with human cortical neurons (HCN1A). Interestingly, upregulated $B A C E 1-A S$ leads to a significant increase in $B A C E 1$ mRNA and rapid feed-forward regulation of $\beta$-secretase, implicating the role of $B A C E 1$ $A S$ in driving AD pathology [19]. RNase protection assay (RPA) further demonstrated that BACE1 and BACE1-AS can form an RNA duplex that stabilizes the complex, protecting it from degradation [19]. Additionally, evidence from a study by Modarresi et al. has demonstrated that knockdown of BACE1- $A S$ in the brains of Tg19959 mouse (a mouse model of $\mathrm{AD}$ ) modulates $\mathrm{A} \beta$ related hippocampal neurogenesis [100]. Another transcript increased in the AD brains, is the IncRNA 51A that is an AS transcript of the $\mathrm{AD}$ associated gene, sortilin-related receptor 1 (SORL1). Its upregulation is associated with an alternative splicing of SORL1, leading to impaired secretion of $\mathrm{A} \beta$ [101].

Glial cell-derived neurotrophic factor (GDNF) is an essential neurotrophic factor that is downregulated in both aging and AD. GDNFOS1 and GDNFOS2 are complementary non-protein coding transcripts of the human GDNF gene [102]. Dysregulated expression of GDNFOS1 and GDNFOS2 in $\mathrm{AD}$ brains has been speculated to contribute to $\mathrm{AD}$ progression and pathogenesis [102, 103]. LncRNA, BC200 RNA (also known as $B C Y R N 1)$ can regulate gene expression at the translational level [104-106]. Interestingly, there exists a close parallel between relative levels of $B C 200$ RNA in the affected brain areas and the progression of $\mathrm{AD}$, as determined by clinical dementia rating scores. Increased perikaryal accumulation of $B C 200$ during advanced stages of the disease likely suggests that aberrant localization and overexpression of $B C 200$ could contribute to synaptodendritic deterioration observed in $\mathrm{AD}$ [107].

Additionally, single-nucleotide polymorphisms (SNPs) within the human genome have been associated with various human diseases. Recent studies have shown that SNPs (rs3217992; rs1063192, and rs1333049) in IncRNA, ANRIL (also known as CDKN2BAS or CDKN2B$A S 1)$ are linked to various physiological and pathological states, such as cardiovascular disease, type 2 diabetes and $\mathrm{AD}$ [108-111]. Furthermore, by reannotation of the microarray data, Zhou and Xu have identified 24 upregulated and 84 downregulated lncRNAs in $\mathrm{AD}$ patients compared with controls [112]. The highly upregulated lncRNA, n336934 (GenBank: BC017047) 
was found to be encoded by the mitochondrial genome and associated with cholesterol homeostasis pathway, that plays a pivotal role in regulating $\mathrm{A} \beta$ formation in $\mathrm{AD}$ [113]. Given that the mitochondrial genome is exclusively maternally inherited in humans, this mitochondrial lncRNA could play an important role in maternally inherited AD [114].

To date, many lncRNAs have been associated with $\mathrm{AD}$ and regulate the expression of $\mathrm{AD}$-associated genes; however, the mechanisms by which lncRNAs affect $\mathrm{AD}$ onset, progression and pathogenesis require further investigation. Thus, lncRNAs hold the potential to be used as biomarkers for AD development and could serve as targets for therapy.

\section{Role of IncRNAs in Huntington's disease (HD)}

Huntington's disease (HD; also known as Huntington's chorea) is an inherited progressive degenerative disorder that develops early in life (40 s or younger). HD results in the death of nerve cells in the brain, leading to movement, cognitive and psychiatric disorders [115]. Available treatments can relieve the symptoms of HD, but do not provide a cure [116]. Human accelerated regions (HARs) represent evolutionary conserved segments of the human genome. Several of the $H A R s$, including lncRNAs, HARIF and $H A R 1 R$, are involved in transcriptional regulation and play an important role in neurodevelopmental processes [117]. In fact, both $H A R 1 F$ and $H A R 1 R$ are significantly downregulated in the striatum of HD patients compared with unaffected individuals [118]. A ChIP-seq (chromatin immunoprecipitation-sequencing) study revealed that $H A R 1 F$ and $H A R 1 R$ are regulated by the transcriptional repressor REST (RE1-silencing transcription factor) and dysregulation of these lncRNAs contributes to neurodegeneration in HD [117]. Similarly, human lncRNA, $h T U N A$ negatively correlates with disease severity in the caudate nucleus of HD brains [119]. At the molecular level, by its interaction with the RNA-Binding Proteins PTBP1, hnRNP-K and Nucleolin, TUNA regulates Sox2 activity. Both TUNA and Sox 2 modulate the expression of 562 genes involved in development, differentiation, neurogenesis, proliferation and neuronal death, indicating the role of lncRNAs in HD progression [119]. Interestingly, lncRNA Abhd11os (known as ABHD11-AS1 in humans)

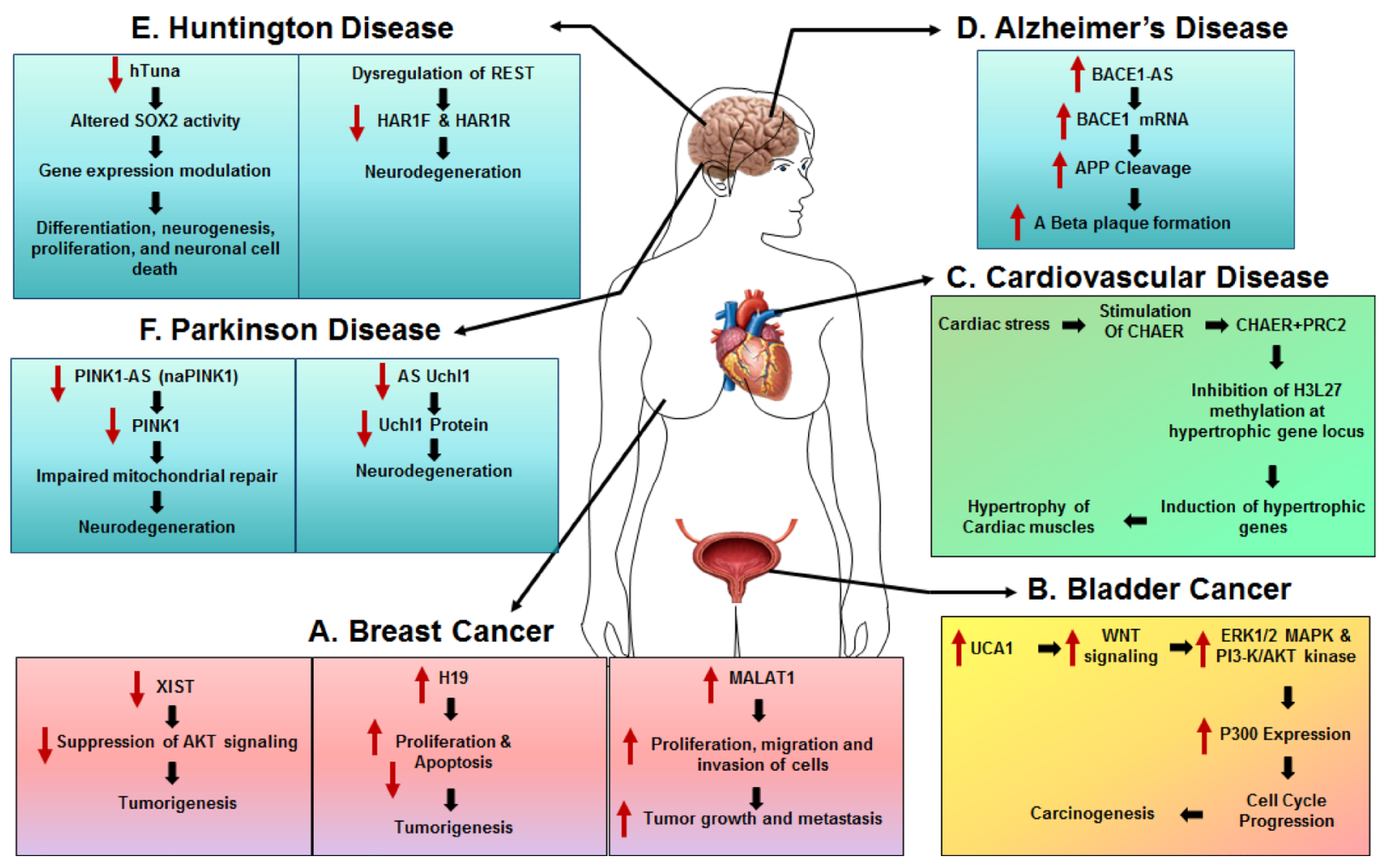

Figure 2: The role of IncRNAs in human diseases. (A) Breast Cancer. LncRNAs, H19 and MALAT1 are both significantly upregulated in breast cancer and are involved in tumorigenesis and tumor growth. LncRNA XIST is downregulated in breast tumor and acts as a tumor suppressor via regulating AKT signaling. (B) Bladder Cancer. LncRNA UCA1 is highly expressed in bladder tumor tissues and promotes cell growth and tumorigenesis. (C) Cardiovascular Disease. Heart-enriched lncRNA, Chaer is upregulated by cardiac stress and is involved in development of cardiac hypertrophy. (D) Alzheimer's Disease. Upregulated lncRNA BACE1-AS led to a significant increase of BACE1 mRNA in AD brains, subsequently exacerbating A $\beta$ plaque formation.(E) Huntington Disease. Human lncRNA hTUNA negatively correlates with severity of Huntington Disease by regulating SOX2 activity. (F) Parkinson Disease. LncRNAs PINK-As and AS Uch1 negatively correlate with severity of Huntington Disease 
is significantly downregulated in the striatum of HD mouse models [120], whereas, forced overexpression of Abhd11os ameliorates neurotoxicity in HD mice, thereby underscoring the role of IncRNAs as potential novel therapeutic targets for HD. Importantly, microarray data from the caudate nucleus of HD brains demonstrated upregulation of $35 \operatorname{lncRNAs}$ and downregulation of 146 lncRNAs compared to matched controls [121]. NEAT1, one of the upregulated lncRNAs in HD [122, 123], showed protective effect against oxidative injury in neuronal cell lines [121]. Although the role of HD-associated lncRNAs is still poorly understood, elucidating lncRNA expression patterns and regulating networks in HD could provide biologic predictors of disease severity, while also shedding light on therapeutic strategies.

\section{Role of IncRNAs in Parkinson's disease (PD)}

Parkinson's disease (PD) is a progressive movement disorder resulting from the loss of dopaminergic neurons in the substantia nigra of the human brain. Currently there is neither a cure nor an exact underlying cause(s) known for PD. Many PD-related genes are associated with mitochondrial function, such as alpha-synuclein, Parkin, PINK1 (phosphatase and tensin homologue induced putative kinase 1), Ubiquitin carboxy-terminal hydrolase L1 (Uchl1), DJ-1 (also known as PD protein 7, PARK7) and LRRK2 (leucine-rich repeat kinase 2), indicating thereby that mitochondrial dysfunction could play a central role in PD pathogenesis [124-126]. PINK1 is a mitochondrial kinase and an upstream factor of Parkin. PINK1 is located in the inner mitochondrial membrane and acts as a recruiter of Parkin to the mitochondria following mitochondrial depolarization. Both proteins together are important for governing mitochondrial dynamics and quality control. In a study Scheele et al. discovered a non-coding antisense transcript expressed at the human PINK1 locus, naPINK1 (also known as PINK1-AS), that can positively regulate a cis-transcribed mRNA - a novel splice variant of PINK1 (svPINK1) which is homologous to the $\mathrm{C}$-terminus regulatory domain of the protein kinase [127]. Northern blotting analysis further demonstrated the expression of $4.4 \mathrm{~kb}$ naPINK1 in 4 neuroblastoma cell lines, including SH-SY5Y, SK-NSH, SK-N-AS and SK-N-F1 [127]. Similarly, Chiba et al. reported enrichment of naPINK1 and PINK1 mRNA in the hippocampus of newborn and 1-week-old mice using in situ hybridization [128]. The role of naPINK1 in mitochondrial dysfunction and PD pathogenesis however, remains to be investigated [129].

In another study by Carrieri et al. it was shown that lncRNA AS Uchl1 (also known as UCHILAS), itself an antisense RNA to the mouse Uchll gene, was enriched in the nucleus of dopaminergic neurons [130] and was found to increase UCHL1 protein synthesis at the post-transcriptional level. Importantly, AS Uchll was significantly downregulated in DA neurons purified from 1-methyl-4-phenyl-1, 2, 3, 6-tetrahydropyridine (MPTP) injected mice (a mouse model of PD) [131]. Since UCHL1 protein has been shown to contribute to the progression of neurodegenerative diseases, AS Uchll, as its upstream regulator, could be envisioned as a new therapeutic target.

In their efforts to discover novel blood-based diagnostic biomarkers for PD, Soreq et al. using RNAseq and comprehensive computational workflow, identified 7,000 brain-expressed lncRNAs, among which $3,495 \operatorname{lncRNAs}$ were also co-expressed in the leukocytes [132]. Of interest, five of these lncRNAs were elevated in PD patients' leukocytes compared to controls and inversely, were decreased following post-deep brain stimulation (DBS). DBS ameliorated PD-induced expression of RP11-79P5.3 in both leukocytes as well as two PD brain regions - the amygdala and substantia nigra, compared with controls.

Additionally, $U 1$ - the spliceosome component as well as RP11-462G22.1 (also known as lnc-FRG1-3 and the muscular dystrophy-associated lncRNA) were increased in both the brain and leukocytes of PD patients, suggesting that lncRNAs could also contribute to splicing modulations and muscle rigidity in PD. Although lncRNAs are enriched in the CNS and are dysregulated in various CNS disorders, including PD, the role of lncRNAs in PD pathogenesis warrants further investigation.

\section{Role of IncRNAs in Prader-Willi syndrome (PWS)}

Prader-Willi syndrome (PWS) is a genetic and neurodevelopmental disorder characterized by retarded growth, obesity, muscular hypotonia and mental deficiency [133]. PWS is caused by the loss of function of specific genes in a particular region of chromosome 15q11-q13. Transcripts from this region are associated with this rare disease. These transcripts include protein-coding mRNAs, such as Ndn (Necdin) and MAGEL2, as well as $\operatorname{lncRNAs}$, such as the class of lncRNAs derived from the SNORD116 snoRNA cluster [134-137]. Yin et al. identified a class of lncRNAs, named sno-lncRNA1-5, that are processed on both ends by the snoRNA machinery [134]. Northern blotting analysis demonstrated that snolncRNAs are expressed in many different cell types, including pluripotent cells such as human ES H9 cells and ovarian carcinoma PA1 cells, but not in HeLa cells [134]. Intriguingly, all five PWS region sno-lncRNAs are retained in the nucleus, co-localize, and accumulate at or near their site of transcription. Crosslinking and immunoprecipitation followed by deep sequencing from human embryonic stem cells using antibodies to Fox2 demonstrated that sno-lncRNAs are strongly associated with the splicing factor Fox2. This study thus suggested that one or more of the sno-lncRNAs from the PWS region could contribute to the pathogenesis of this disease by acting as a molecular sink for Fox proteins [134]. 
Another lncRNA transcribed from SNORD116 snoRNA cluster, $116 H G$ can bind to RBBP5 and to the gene promoters genome-wide and form RNA cloud nuclear domains in both mouse and human adult neuronal nuclei [138]. Furthermore, $116 H G$ regulates the diurnal energy expenditure of the brain which provides a novel mechanism underlying sleep problems in PWS patients [138]. In contrast to $116 H G$, lncRNA, IPW (Imprinted gene in the Prader-Willi syndrome region), is expressed in the cytoplasm [139]. As $I P W$ is located in the 15q11-q13 region, PWS patients do not express $I P W$ [139]. Recently, a study of atypical submicroscopic 15q11-q13 deletions in five PWS patients demonstrated a critical deletion region involving the non-coding snoRNA SNORD116, SNORD109A and IPW that was common in all the five individuals, further supporting the role of these lncRNAs in the pathogenesis of PWS [140].

\section{Role of IncRNAs in fragile X syndrome (FXS)}

Fragile X syndrome (FXS) is a genetic disorder caused by a mutation of the fragile $\mathrm{X}$ mental retardation 1 (FMRl) gene on the $\mathrm{X}$ chromosome. It is typically due to an increase in the number of CGG trinucleotide repeats in the 5' untranslated region of FMRl. The abnormally expanded CGG segment results in silencing of the FMR1 gene with subsequent abnormalities in the formation and function of synapses [141]. Intriguingly, several lncRNAs, including FMR4, FMR5, FMR6 and FMR1-AS, are transcribed from the FMR1 gene locus as well [142]. Using gene expression microarrays, Peschansky et al. identified a wide array of FMR4-responsive genes, suggesting a broad role of FMR4 [143]. Further analysis confirmed that FMR4 was involved in cell proliferation, differentiation as well as apoptosis [143]. Using Deep-RACE (rapid amplification of cDNA ends) with sequencing, Pastori et al. discovered two lncRNAs, FMR5 and FMR6 [144] that are transcribed upstream of the FMR1 promoter, and antisense of the $3^{\prime}$ region of FMR1, respectively. RT-PCR analysis demonstrated that FMR5 and FMR6 are expressed in most adult brain regions, including the adult human cerebellum, frontal and temporal lobes, occipital and cerebral cortices and hippocampii, as well as in the fetal brain [144]. The expression of FMR6 was found to be significantly decreased in the brain of FXS individuals compared with that of the controls [144]. The expression of FMR5 however, remained unchanged in the brains of FXS individuals [144]. While the expression pattern of these lncRNAs has been determined, efforts aimed at deciphering their functional properties warrants investigation.

\section{CHALLENGES AND PERSPECTIVES}

Tremendous progress has been made in recent years in understanding the mechanisms of action underlying lncRNAs. LncRNAs not only act as transcriptional and post- transcriptional regulators of gene expression, but are also emerging as catalytic enzymes. The rapidly expanding body of work on lncRNAs provides evidence that it is feasible to develop computational models that can successfully predict lncRNA structure and function. Additionally, although many studies have been performed in clinical patients using various disease models, the exact role and impact of lncRNAs in disease pathogenesis still remains obscure. Further efforts are required to understand the impact of lncRNAs in all realms of research including basic, translational, clinical and pharmaceutical sciences with specific emphasis on their role in genetic, metabolic, infectious, cancer and age-related diseases.

\section{ACKNOWLEDGMENTS}

This work was supported by grants MH112848, DA040397, DA043138, MH106425, DA044586 (SB), DA033150 (GH) and DA042704 (GH) from the National Institutes of Health. The support by Nebraska Center for Substance Abuse Research is acknowledged. The project described was also supported by the NIH, National Institute of Mental Health, 2P30MH062261. The content is solely the responsibility of the authors and does not necessarily represent the official views of the NIH.

\section{CONFLICTS OF INTEREST}

The authors declare no conflicts of interest.

\section{REFERENCES}

1. Wang $\mathrm{KC}$, Chang HY. Molecular mechanisms of long noncoding RNAs. Mol Cell. 2011; 43:904-914.

2. Hombach S, Kretz M. The non-coding skin: exploring the roles of long non-coding RNAs in epidermal homeostasis and disease. Bioessays. 2013; 35:1093-1100.

3. Shore AN, Rosen JM. Regulation of mammary epithelial cell homeostasis by lncRNAs. Int J Biochem Cell Biol. 2014; 54:318-330.

4. Coll-Bonfill N, de la Cruz-Thea B, Pisano MV, Musri MM. Noncoding RNAs in smooth muscle cell homeostasis: implications in phenotypic switch and vascular disorders. Pflugers Arch. 2016; 468:1071-1087.

5. Chen Z. Progress and prospects of long noncoding RNAs in lipid homeostasis. Mol Metab. 2016; 5:164-170.

6. Wapinski O, Chang HY. Long noncoding RNAs and human disease. Trends Cell Biol. 2011; 21:354-361.

7. Spizzo R, Almeida MI, Colombatti A, Calin GA. Long noncoding RNAs and cancer: a new frontier of translational research? Oncogene. 2012; 31:4577-87.

8. Reis EM, Verjovski-Almeida S. Perspectives of Long NonCoding RNAs in Cancer Diagnostics. Front Genet. 2012; 3:32.

9. Carlson HL, Quinn JJ, Yang YW, Thornburg CK, Chang HY, Stadler HS. LncRNA-HIT Functions as an Epigenetic 
Regulator of Chondrogenesis through Its Recruitment of p100/CBP Complexes. PLoS Genet. 2015; 11:e1005680.

10. He Y, Ding Y, Zhan F, Zhang H, Han B, Hu G, Zhao K, Yang N, Yu Y, Mao L, Song J. The conservation and signatures of lincRNAs in Marek's disease of chicken. Sci Rep. 2015; 5:15184.

11. Jalali S, Kapoor S, Sivadas A, Bhartiya D, Scaria V. Computational approaches towards understanding human long non-coding RNA biology. Bioinformatics. 2015; 31:2241-2251.

12. Volders PJ, Verheggen K, Menschaert G, Vandepoele K, Martens L, Vandesompele J, Mestdagh P. An update on LNCipedia: a database for annotated human lncRNA sequences. Nucleic Acids Res. 2015; 43:4363-4364.

13. Harrow J, Frankish A, Gonzalez JM, Tapanari E, Diekhans M, Kokocinski F, Aken BL, Barrell D, Zadissa A, Searle S, Barnes I, Bignell A, Boychenko V, et al. GENCODE: the reference human genome annotation for The ENCODE Project. Genome Res. 2012; 22:1760-1774.

14. Kozomara A, Griffiths-Jones S. miRBase: annotating high confidence microRNAs using deep sequencing data. Nucleic Acids Res. 2014; 42:D68-73.

15. Martone R, Euskirchen G, Bertone P, Hartman S, Royce TE, Luscombe NM, Rinn JL, Nelson FK, Miller P, Gerstein M, Weissman S, Snyder M. Distribution of NF-kappaB-binding sites across human chromosome 22. Proc Natl Acad Sci U S A. 2003; 100:12247-12252.

16. Guttman M, Amit I, Garber M, French C, Lin MF, Feldser D, Huarte M, Zuk O, Carey BW, Cassady JP, Cabili MN, Jaenisch R, Mikkelsen TS, et al. Chromatin signature reveals over a thousand highly conserved large non-coding RNAs in mammals. Nature. 2009; 458:223-227.

17. Hu G, Gong AY, Wang Y, Ma S, Chen X, Chen J, Su CJ, Shibata A, Strauss-Soukup JK, Drescher KM, Chen XM. LincRNA-Cox2 Promotes Late Inflammatory Gene Transcription in Macrophages through Modulating SWI/ SNF-Mediated Chromatin Remodeling. J Immunol. 2016; 196:2799-2808.

18. Tong Q, Gong AY, Zhang XT, Lin C, Ma S, Chen J, Hu G, Chen XM. LincRNA-Cox2 modulates TNF-alpha-induced transcription of $1112 \mathrm{~b}$ gene in intestinal epithelial cells through regulation of $\mathrm{Mi}-2 / \mathrm{NuRD}-$ mediated epigenetic histone modifications. FASEB J. 2016; 30:1187-1197.

19. Faghihi MA, Modarresi F, Khalil AM, Wood DE, Sahagan BG, Morgan TE, Finch CE, Laurent GS, Kenny PJ, Wahlestedt C. Expression of a noncoding RNA is elevated in Alzheimer's disease and drives rapid feed-forward regulation of beta-secretase. Nat Med. 2008; 14:723-730.

20. Audas TE, Lee S. Stressing out over long noncoding RNA. Biochim Biophys Acta. 2016; 1859:184-191.

21. Valgardsdottir R, Chiodi I, Giordano M, Rossi A, Bazzini S, Ghigna C, Riva S, Biamonti G. Transcription of Satellite III non-coding RNAs is a general stress response in human cells. Nucleic Acids Res. 2008; 36:423-434.
22. Zhang F, Zhang L, Zhang C. Long noncoding RNAs and tumorigenesis: genetic associations, molecular mechanisms, and therapeutic strategies. Tumour Biol. 2016; 37:163-175.

23. Li T, Mo X, Fu L, Xiao B, Guo J. Molecular mechanisms of long noncoding RNAs on gastric cancer. Oncotarget. 2016; 7:8601-8612. https://doi.org/10.18632/oncotarget.6926.

24. Fu M, Zou C, Pan L, Liang W, Qian H, Xu W, Jiang P, Zhang X. Long noncoding RNAs in digestive system cancers: Functional roles, molecular mechanisms, and clinical implications (Review). Oncol Rep. 2016; 36:1207-1218.

25. Knoll M, Lodish HF, Sun L. Long non-coding RNAs as regulators of the endocrine system. Nat Rev Endocrinol. 2015; 11:151-160.

26. Andrew J. Warburton, Boone DN. Insights from Global Analyses of Long Noncoding RNAs in Breast Cancer. Current Pathobiology Reports. 2017; 5:23-24.

27. Rinn JL, Kertesz M, Wang JK, Squazzo SL, Xu X, Brugmann SA, Goodnough LH, Helms JA, Farnham PJ, Segal E, Chang HY. Functional demarcation of active and silent chromatin domains in human HOX loci by noncoding RNAs. Cell. 2007; 129:1311-1323.

28. Yap KL, Li S, Munoz-Cabello AM, Raguz S, Zeng L, Mujtaba S, Gil J, Walsh MJ, Zhou MM. Molecular interplay of the noncoding RNA ANRIL and methylated histone H3 lysine 27 by polycomb CBX7 in transcriptional silencing of INK4a. Mol Cell. 2010; 38:662-674.

29. Kotake Y, Nakagawa T, Kitagawa K, Suzuki S, Liu N, Kitagawa M, Xiong Y. Long non-coding RNA ANRIL is required for the PRC2 recruitment to and silencing of p15(INK4B) tumor suppressor gene. Oncogene. 2011; 30:1956-1962.

30. Zhao J, Sun BK, Erwin JA, Song JJ, Lee JT. Polycomb proteins targeted by a short repeat RNA to the mouse X chromosome. Science. 2008; 322:750-756.

31. Bernstein E, Duncan EM, Masui O, Gil J, Heard E, Allis CD. Mouse polycomb proteins bind differentially to methylated histone $\mathrm{H} 3$ and RNA and are enriched in facultative heterochromatin. Mol Cell Biol. 2006; 26:2560-2569.

32. Kapranov P, Cheng J, Dike S, Nix DA, Duttagupta R, Willingham AT, Stadler PF, Hertel J, Hackermuller J, Hofacker IL, Bell I, Cheung E, Drenkow J, et al. RNA maps reveal new RNA classes and a possible function for pervasive transcription. Science. 2007; 316:1484-1488.

33. Blume SW, Meng Z, Shrestha K, Snyder RC, Emanuel PD. The 5'-untranslated RNA of the human dhfr minor transcript alters transcription pre-initiation complex assembly at the major (core) promoter. J Cell Biochem. 2003; 88:165-180.

34. Fujii $\mathrm{H}$, Shimada $\mathrm{T}$. Isolation and characterization of cDNA clones derived from the divergently transcribed gene in the region upstream from the human dihydrofolate reductase gene. J Biol Chem. 1989; 264:10057-10064. 
35. Masters JN, Attardi G. Discrete human dihydrofolate reductase gene transcripts present in polysomal RNA map with their 5' ends several hundred nucleotides upstream of the main mRNA start site. Mol Cell Biol. 1985; 5:493-500.

36. Martianov I, Ramadass A, Serra Barros A, Chow N, Akoulitchev A. Repression of the human dihydrofolate reductase gene by a non-coding interfering transcript. Nature. 2007; 445:666-670.

37. Villegas VE, Zaphiropoulos PG. Neighboring gene regulation by antisense long non-coding RNAs. Int J Mol Sci. 2015; 16:3251-3266.

38. Beckedorff FC, Ayupe AC, Crocci-Souza R, Amaral MS, Nakaya HI, Soltys DT, Menck CF, Reis EM, VerjovskiAlmeida $\mathrm{S}$. The intronic long noncoding RNA ANRASSF1 recruits $\mathrm{PRC} 2$ to the RASSF1A promoter, reducing the expression of RASSF1A and increasing cell proliferation. PLoS Genet. 2013; 9:e1003705.

39. Hu S, Wang X, Shan G. Insertion of an Alu element in a lncRNA leads to primate-specific modulation of alternative splicing. Nat Struct Mol Biol. 2016; 23:1011-1019.

40. Johnsson P, Ackley A, Vidarsdottir L, Lui WO, Corcoran M, Grander D, Morris KV. A pseudogene long-noncodingRNA network regulates PTEN transcription and translation in human cells. Nat Struct Mol Biol. 2013; 20:440-446.

41. Song P, Yin SC. Long non-coding RNA EWSAT1 promotes human nasopharyngeal carcinoma cell growth in vitro by targeting miR-326/-330-5p. Aging (Albany NY). 2016; 8:2948-2960. https://doi.org/10.18632/aging.101103.

42. Paci P, Colombo T, Farina L. Computational analysis identifies a sponge interaction network between long noncoding RNAs and messenger RNAs in human breast cancer. BMC Syst Biol. 2014; 8:83.

43. Du Z, Sun T, Hacisuleyman E, Fei T, Wang X, Brown M, Rinn JL, Lee MG, Chen Y, Kantoff PW, Liu XS. Integrative analyses reveal a long noncoding RNA-mediated sponge regulatory network in prostate cancer. Nat Commun. 2016; 7:10982.

44. Matsumoto A, Pasut A, Matsumoto M, Yamashita R, Fung J, Monteleone E, Saghatelian A, Nakayama KI, Clohessy JG, Pandolfi PP. mTORC1 and muscle regeneration are regulated by the LINC00961-encoded SPAR polypeptide. Nature. 2017; 541:228-232.

45. Anderson DM, Anderson KM, Chang CL, Makarewich CA, Nelson BR, McAnally JR, Kasaragod P, Shelton JM, Liou J, Bassel-Duby R, Olson EN. A micropeptide encoded by a putative long noncoding RNA regulates muscle performance. Cell. 2015; 160:595-606.

46. Nelson BR, Makarewich CA, Anderson DM, Winders BR, Troupes CD, Wu F, Reese AL, McAnally JR, Chen X, Kavalali ET, Cannon SC, Houser SR, Bassel-Duby R, et al. A peptide encoded by a transcript annotated as long noncoding RNA enhances SERCA activity in muscle. Science. 2016; 351:271-275.
47. Ruiz-Orera J, Messeguer X, Subirana JA, Alba MM. Long non-coding RNAs as a source of new peptides. Elife. 2014; 3:e03523.

48. Slavoff SA, Mitchell AJ, Schwaid AG, Cabili MN, Ma J, Levin JZ, Karger AD, Budnik BA, Rinn JL, Saghatelian A. Peptidomic discovery of short open reading frame-encoded peptides in human cells. Nat Chem Biol. 2013; 9:59-64.

49. Cech TR. Self-splicing of group I introns. Annu Rev Biochem. 1990; 59:543-568.

50. Wu S, Mao G, Kirsebom LA. Inhibition of Bacterial RNase P RNA by Phenothiazine Derivatives. Biomolecules. $2016 ; 6$.

51. Guerrier-Takada C, Gardiner K, Marsh T, Pace N, Altman S. The RNA moiety of ribonuclease $\mathrm{P}$ is the catalytic subunit of the enzyme. Cell. 1983; 35:849-857.

52. Brimacombe R, Stiege W. Structure and function of ribosomal RNA. Biochem J. 1985; 229:1-17.

53. Ferre-D'Amare AR, Scott WG. Small self-cleaving ribozymes. Cold Spring Harb Perspect Biol. 2010; 2:a003574.

54. Yang Y, Junjie P, Sanjun C, Ma Y. Long non-coding RNAs in Colorectal Cancer: Progression and Future Directions. J Cancer. 2017; 8:3212-3225.

55. Li H, Ma SQ, Huang J, Chen XP, Zhou HH. Roles of long noncoding RNAs in colorectal cancer metastasis. Oncotarget. 2017; 8:39859-39876. https://doi.org/10.18632/ oncotarget.16339.

56. Misawa A, Takayama KI, Inoue S. Long non-coding RNAs and prostate cancer. Cancer Sci. 2017; 108:2107-2114.

57. Ghiam AF, Vesprini D, Liu SK. Long non-coding RNAs: new frontiers for advancing personalized cancer medicine in prostate cancer. Transl Androl Urol. 2017; 6:326-330.

58. Smolle MA, Bauernhofer T, Pummer K, Calin GA, Pichler M. Current Insights into Long Non-Coding RNAs (LncRNAs) in Prostate Cancer. Int J Mol Sci. 2017; 18.

59. Tang Y, Zhou T, Yu X, Xue Z, Shen N. The role of long noncoding RNAs in rheumatic diseases. Nat Rev Rheumatol. 2017; 13:657-669.

60. Peng F, Li TT, Wang KL, Xiao GQ, Wang JH, Zhao HD, Kang ZJ, Fan WJ, Zhu LL, Li M, Cui B, Zheng FM, Wang HJ, et al. H19/let-7/LIN28 reciprocal negative regulatory circuit promotes breast cancer stem cell maintenance. Cell Death Dis. 2017; 8:e2569.

61. Berteaux N, Lottin S, Monte D, Pinte S, Quatannens B, Coll J, Hondermarck H, Curgy JJ, Dugimont T, Adriaenssens E. H19 mRNA-like noncoding RNA promotes breast cancer cell proliferation through positive control by E2F1. J Biol Chem. 2005; 280:29625-29636.

62. Yballe CM, Vu TH, Hoffman AR. Imprinting and expression of insulin-like growth factor-II and H19 in normal breast tissue and breast tumor. J Clin Endocrinol Metab. 1996; 81:1607-1612.

63. Matouk IJ, Raveh E, Abu-lail R, Mezan S, Gilon M, Gershtain E, Birman T, Gallula J, Schneider T, Barkali M, 
Richler C, Fellig Y, Sorin V, et al. Oncofetal H19 RNA promotes tumor metastasis. Biochim Biophys Acta. 2014; 1843:1414-1426.

64. Sun H, Wang G, Peng Y, Zeng Y, Zhu QN, Li TL, Cai JQ, Zhou HH, Zhu YS. H19 lncRNA mediates 17beta-estradiolinduced cell proliferation in MCF-7 breast cancer cells. Oncol Rep. 2015; 33:3045-3052.

65. Zhao Z, Chen C, Liu Y, Wu C. 17beta-Estradiol treatment inhibits breast cell proliferation, migration and invasion by decreasing MALAT-1 RNA level. Biochem Biophys Res Commun. 2014; 445:388-393.

66. Jadaliha M, Zong X, Malakar P, Ray T, Singh DK, Freier SM, Jensen T, Prasanth SG, Karni R, Ray PS, Prasanth KV. Functional and prognostic significance of long non-coding RNA MALAT1 as a metastasis driver in ER negative lymph node negative breast cancer. Oncotarget. 2016; 7:4041840436. https://doi.org/10.18632/oncotarget.9622.

67. Huang NS, Chi YY, Xue JY, Liu MY, Huang S, Mo M, Zhou $\mathrm{SL}$, Wu J. Long non-coding RNA metastasis associated in lung adenocarcinoma transcript 1 (MALAT1) interacts with estrogen receptor and predicted poor survival in breast cancer. Oncotarget. 2016; 7:37957-37965. https://doi. org/10.18632/oncotarget.9364.

68. Miao Y, Fan R, Chen L, Qian H. Clinical Significance of Long Non-coding RNA MALAT1 Expression in Tissue and Serum of Breast Cancer. Ann Clin Lab Sci. 2016; 46:418-424.

69. Mendell JT. Targeting a Long Noncoding RNA in Breast Cancer. N Engl J Med. 2016; 374:2287-2289.

70. Niknafs YS, Han S, Ma T, Speers C, Zhang C, WilderRomans K, Iyer MK, Pitchiaya S, Malik R, Hosono Y, Prensner JR, Poliakov A, Singhal U, et al. The lncRNA landscape of breast cancer reveals a role for DSCAM-AS1 in breast cancer progression. Nat Commun. 2016; 7:12791.

71. Miano V, Ferrero G, Reineri S, Caizzi L, Annaratone L, Ricci L, Cutrupi S, Castellano I, Cordero F, De Bortoli M. Luminal long non-coding RNAs regulated by estrogen receptor alpha in a ligand-independent manner show functional roles in breast cancer. Oncotarget. 2016; 7:3201-3216. https://doi. org/10.18632/oncotarget.6420.

72. Van Grembergen O, Bizet M, de Bony EJ, Calonne E, Putmans P, Brohee S, Olsen C, Guo M, Bontempi G, Sotiriou C, Defrance M, Fuks F. Portraying breast cancers with long noncoding RNAs. Sci Adv. 2016; 2:e1600220.

73. Soudyab M, Iranpour M, Ghafouri-Fard S. The Role of Long Non-Coding RNAs in Breast Cancer. Arch Iran Med. 2016; 19:508-517.

74. Warburton AJ, Boone DN. Insights from Global Analyses of Long Noncoding RNAs in Breast 696 Cancer. Curr Pathobiol Rep. 2017; 5:23-34.

75. Zhang C, Suckow AT, Chessler SD. Altered pancreatic islet function and morphology in mice lacking the Beta-cell surface protein neuroligin-2. PLoS One. 2013; 8:e65711.
76. Martens-Uzunova ES, Bottcher R, Croce CM, Jenster G, Visakorpi T, Calin GA. Long noncoding RNA in prostate, bladder, and kidney cancer. Eur Urol. 2014; 65:1140-1151.

77. Chen Z, Liu Y, He A, Li J, Chen M, Zhan Y, Lin J, Zhuang C, Liu L, Zhao G, Huang W, Cai Z. Theophylline controllable RNAi-based genetic switches regulate expression of IncRNA TINCR and malignant phenotypes in bladder cancer cells. Sci Rep. 2016; 6:30798.

78. He A, Liu Y, Chen Z, Li J, Chen M, Liu L, Liao X, Lv Z, Zhan Y, Zhuang C, Lin J, Huang W, Mei H. Overexpression of long noncoding RNA BANCR inhibits malignant phenotypes of human bladder cancer. J Exp Clin Cancer Res. 2016; 35:125.

79. Elkin M, Shevelev A, Schulze E, Tykocinsky M, Cooper M, Ariel I, Pode D, Kopf E, de Groot N, Hochberg A. The expression of the imprinted H19 and IGF-2 genes in human bladder carcinoma. FEBS Letters. 1995; 374:57-61.

80. Ariel I, Lustig O, Schneider T, Pizov G, Sappir M, De-Groot $\mathrm{N}$, Hochberg A. The imprinted $\mathrm{H} 19$ gene as a tumor marker in bladder carcinoma. Urology. 1995; 45:335-338.

81. Luo M, Li Z, Wang W, Zeng Y, Liu Z, Qiu J. Upregulated H19 contributes to bladder cancer cell proliferation by regulating ID2 expression. FEBS J. 2013; 280:1709-1716.

82. Luo M, Li Z, Wang W, Zeng Y, Liu Z, Qiu J. Long noncoding RNA H19 increases bladder cancer metastasis by associating with EZH2 and inhibiting E-cadherin expression. Cancer Lett. 2013; 333:213-221.

83. Srivastava AK, Singh PK, Rath SK, Dalela D, Goel MM, Bhatt ML. Appraisal of diagnostic ability of UCA1 as a biomarker of carcinoma of the urinary bladder. Tumour Biol. 2014; 35:11435-11442.

84. Milowich D, Le Mercier M, De Neve N, Sandras F, Roumeguere T, Decaestecker C, Salmon I, Rorive S. Diagnostic value of the UCA1 test for bladder cancer detection: a clinical study. Springerplus. 2015; 4:349.

85. Eissa S, Matboli M, Essawy NO, Kotb YM. Integrative functional genetic-epigenetic approach for selecting genes as urine biomarkers for bladder cancer diagnosis. Tumour Biol. 2015; 36:9545-9552.

86. Wang XS, Zhang Z, Wang HC, Cai JL, Xu QW, Li MQ, Chen YC, Qian XP, Lu TJ, Yu LZ, Zhang Y, Xin DQ, Na $Y Q$, et al. Rapid identification of UCA1 as a very sensitive and specific unique marker for human bladder carcinoma. Clin Cancer Res. 2006; 12:4851-4858.

87. Wang F, Li X, Xie X, Zhao L, Chen W. UCA1, a nonprotein-coding RNA up-regulated in bladder carcinoma and embryo, influencing cell growth and promoting invasion. FEBS Letters. 2008; 582:1919-1927.

88. Wang Y, Chen W, Yang C, Wu W, Wu S, Qin X, Li X. Long non-coding RNA UCA1a(CUDR) promotes proliferation and tumorigenesis of bladder cancer. Int J Oncol. 2012; 41:276-284.

89. Xue M, Li X, Wu W, Zhang S, Wu S, Li Z, Chen W. Upregulation of long non-coding RNA urothelial carcinoma 
associated 1 by CCAAT/enhancer binding protein alpha contributes to bladder cancer cell growth and reduced apoptosis. Oncol Rep. 2014; 31:1993-2000.

90. Fan Y, Shen B, Tan M, Mu X, Qin Y, Zhang F, Liu Y. Long non-coding RNA UCA1 increases chemoresistance of bladder cancer cells by regulating Wnt signaling. FEBS J. 2014; 281:1750-1758.

91. Iliev R, Kleinova R, Juracek J, Dolezel J, Ozanova Z, Fedorko M, Pacik D, Svoboda M, Stanik M, Slaby O. Overexpression of long non-coding RNA TUG1 predicts poor prognosis and promotes cancer cell proliferation and migration in high-grade muscle-invasive bladder cancer. Tumour Biol. 2016; 37:13385-13390.

92. Wang J, Ye C, Xiong H, Shen Y, Lu Y, Zhou J, Wang L. Dysregulation of long non-coding RNA in breast cancer: an overview of mechanism and clinical implication. Oncotarget. 2017; 8:5508-5522. https://doi.org/10.18632/ oncotarget. 12537.

93. Zeng T, Wang D, Chen J, Tian Y, Cai X, Peng H, Zhu L, Huang A, Tang H. LncRNA-AF113014 promotes the expression of Egr2 by interaction with miR-20a to inhibit proliferation of hepatocellular carcinoma cells. PLoS One. 2017; 12:e0177843.

94. Leucci E, Coe EA, Marine JC, Vance KW. The emerging role of long non-coding RNAs in cutaneous melanoma. Pigment Cell Melanoma Res. 2016; 29:619-626.

95. Lee JH, Gao C, Peng G, Greer C, Ren S, Wang Y, Xiao $\mathrm{X}$. Analysis of transcriptome complexity through RNA sequencing in normal and failing murine hearts. Circ Res. 2011; 109:1332-1341.

96. Yang KC, Yamada KA, Patel AY, Topkara VK, George I, Cheema FH, Ewald GA, Mann DL, Nerbonne JM. Deep RNA sequencing reveals dynamic regulation of myocardial noncoding RNAs in failing human heart and remodeling with mechanical circulatory support. Circulation. 2014; 129:1009-1021.

97. Han P, Li W, Lin CH, Yang J, Shang C, Nurnberg ST, Jin $\mathrm{KK}, \mathrm{Xu} \mathrm{W}$, Lin $\mathrm{CY}$, Lin CJ, Xiong Y, Chien HC, Zhou $\mathrm{B}$, et al. A long noncoding RNA protects the heart from pathological hypertrophy. Nature. 2014; 514:102-106.

98. Wang Z, Zhang XJ, Ji YX, Zhang P, Deng KQ, Gong J, Ren S, Wang X, Chen I, Wang H, Gao C, Yokota T, Ang YS, et al. The long noncoding RNA Chaer defines an epigenetic checkpoint in cardiac hypertrophy. Nat Med. 2016; 22:1131-1139.

99. Busciglio J, Gabuzda DH, Matsudaira P, Yankner BA. Generation of beta-amyloid in the secretory pathway in neuronal and nonneuronal cells. Proc Natl Acad Sci U S A. 1993; 90:2092-2096.

100. Modarresi F, Faghihi MA, Patel NS, Sahagan BG, Wahlestedt C, Lopez-Toledano MA. Knockdown of BACE1-AS Nonprotein-Coding Transcript Modulates BetaAmyloid-Related Hippocampal Neurogenesis. International Journal of Alzheimer's Disease. 2011; 2011:929042.
101. Ciarlo E, Massone S, Penna I, Nizzari M, Gigoni A, Dieci G, Russo C, Florio T, Cancedda R, Pagano A. An intronic ncRNA-dependent regulation of SORL1 expression affecting Abeta formation is upregulated in post-mortem Alzheimer's disease brain samples. Dis Model Mech. 2013; 6:424-433.

102. Airavaara M, Pletnikova O, Doyle ME, Zhang YE, Troncoso JC, Liu QR. Identification of novel GDNF isoforms and cis-antisense GDNFOS gene and their regulation in human middle temporal gyrus of Alzheimer disease. The Journal of Biological Chemistry. 2011; 286:45093-45102.

103. Wu P, Zuo X, Deng H, Liu X, Liu L, Ji A. Roles of long noncoding RNAs in brain development, functional diversification and neurodegenerative diseases. Brain Res Bull. 2013; 97:69-80.

104. Muslimov IA, Iacoangeli A, Brosius J, Tiedge H. Spatial codes in dendritic BC1 RNA. The Journal of Cell Biology. 2006; 175:427-439.

105. Muddashetty R, Khanam T, Kondrashov A, Bundman M, Iacoangeli A, Kremerskothen J, Duning K, Barnekow A, Huttenhofer A, Tiedge H, Brosius J. Poly(A)-binding protein is associated with neuronal $\mathrm{BC} 1$ and $\mathrm{BC} 200$ ribonucleoprotein particles. Journal of Molecular Biology. 2002; 321:433-445.

106. Duning K, Buck F, Barnekow A, Kremerskothen J. SYNCRIP, a component of dendritically localized mRNPs, binds to the translation regulator BC200 RNA. J Neurochem. 2008; 105:351-359.

107. Mus E, Hof PR, Tiedge H. Dendritic BC200 RNA in aging and in Alzheimer's disease. Proceedings of the National Academy of Sciences of the United States of America. 2007; 104:10679-10684.

108. Hrdlickova B, de Almeida RC, Borek Z, Withoff S. Genetic variation in the non-coding genome: Involvement of microRNAs and long non-coding RNAs in disease. Biochim Biophys Acta. 2014; 1842:1910-1922.

109. Zhao J, Wu X, Nie S, Gao X, Sun J, Li K, Zhang T, Huang Y. Association of CDKN2B-AS1 rs1333049 with Brain Diseases: A Case-control Study and a Meta-analysis. Clin Psychopharmacol Neurosci. 2017; 15:53-58.

110. Pasmant E, Sabbagh A, Vidaud M, Bieche I. ANRIL, a long, noncoding RNA, is an unexpected major hotspot in GWAS. FASEB J. 2011; 25:444-448.

111. Burd CE, Jeck WR, Liu Y, Sanoff HK, Wang Z, Sharpless NE. Expression of linear and novel circular forms of an INK4/ARF-associated non-coding RNA correlates with atherosclerosis risk. PLoS Genet. 2010; 6:e1001233.

112. Zhou X, Xu J. Identification of Alzheimer's diseaseassociated long noncoding RNAs. Neurobiol Aging. 2015; 36:2925-2931.

113. Hannaoui S, Shim SY, Cheng YC, Corda E, Gilch S. Cholesterol balance in prion diseases and Alzheimer's disease. Viruses. 2014; 6:4505-4535.

114. Mosconi L, Berti V, Swerdlow RH, Pupi A, Duara R, de Leon M. Maternal transmission of Alzheimer's disease: 
prodromal metabolic phenotype and the search for genes. Hum Genomics. 2010; 4:170-193.

115. Roos RA. Huntington's disease: a clinical review. Orphanet J Rare Dis. 2010; 5:40.

116. Dayalu P, Albin RL. Huntington disease: pathogenesis and treatment. Neurol Clin. 2015; 33:101-114.

117. Pollard KS, Salama SR, Lambert N, Lambot MA, Coppens S, Pedersen JS, Katzman S, King B, Onodera C, Siepel A, Kern AD, Dehay C, Igel H, et al. An RNA gene expressed during cortical development evolved rapidly in humans. Nature. 2006; 443:167-172.

118. Johnson R, Richter N, Jauch R, Gaughwin PM, Zuccato C, Cattaneo E, Stanton LW. Human accelerated region 1 noncoding RNA is repressed by REST in Huntington's disease. Physiol Genomics. 2010; 41:269-274.

119. Lin N, Chang KY, Li Z, Gates K, Rana ZA, Dang J, Zhang D, Han T, Yang CS, Cunningham TJ, Head SR, Duester G, Dong PD, et al. An evolutionarily conserved long noncoding RNA TUNA controls pluripotency and neural lineage commitment. Molecular Cell. 2014; 53:1005-1019.

120. Francelle L, Galvan L, Gaillard MC, Petit F, Bernay B, Guillermier M, Bonvento G, Dufour N, Elalouf JM, Hantraye P, Deglon N, de Chaldee M, Brouillet E. Striatal long noncoding RNA Abhd11os is neuroprotective against an N-terminal fragment of mutant huntingtin in vivo. Neurobiol Aging. 2015; 36:1601 e1607-1616.

121. Sunwoo JS, Lee ST, Im W, Lee M, Byun JI, Jung KH, Park KI, Jung KY, Lee SK, Chu K, Kim M. Altered Expression of the Long Noncoding RNA NEAT1 in Huntington's Disease. Molecular Neurobiology. 2017; 54:1577-1586.

122. Hodges A, Strand AD, Aragaki AK, Kuhn A, Sengstag T, Hughes G, Elliston LA, Hartog C, Goldstein DR, Thu D, Hollingsworth ZR, Collin F, Synek B, et al. Regional and cellular gene expression changes in human Huntington's disease brain. Hum Mol Genet. 2006; 15:965-977.

123. Johnson R. Long non-coding RNAs in Huntington's disease neurodegeneration. Neurobiol Dis. 2012; 46:245-254.

124. Exner N, Lutz AK, Haass C, Winklhofer KF. Mitochondrial dysfunction in Parkinson's disease: molecular mechanisms and pathophysiological consequences. The EMBO Journal. 2012; 31:3038-3062.

125. Hu Q, Wang G. Mitochondrial dysfunction in Parkinson's disease. Transl Neurodegener. 2016; 5:14.

126. Bose A, Beal MF. Mitochondrial dysfunction in Parkinson's disease. J Neurochem. 2016; 139 Suppl 1:216-231.

127. Scheele C, Petrovic N, Faghihi MA, Lassmann T, Fredriksson K, Rooyackers O, Wahlestedt C, Good L, Timmons JA. The human PINK1 locus is regulated in vivo by a non-coding natural antisense RNA during modulation of mitochondrial function. BMC Genomics. 2007; 8:74.

128. Chiba M, Kiyosawa H, Hiraiwa N, Ohkohchi N, Yasue $\mathrm{H}$. Existence of Pink1 antisense RNAs in mouse and their localization. Cytogenet Genome Res. 2009; 126:259-270.
129. Kou X, Liu X, Chen X, Li J, Yang X, Fan J, Yang Y, Chen N. Ampelopsin attenuates brain aging of D-gal-induced rats through miR-34a-mediated SIRT1/mTOR signal pathway. Oncotarget. 2016; 7:74484-74495. https://doi. org/10.18632/oncotarget.12811.

130. Carrieri C, Cimatti L, Biagioli M, Beugnet A, Zucchelli S, Fedele S, Pesce E, Ferrer I, Collavin L, Santoro C, Forrest AR, Carninci P, Biffo S, et al. Long non-coding antisense RNA controls Uchl1 translation through an embedded SINEB2 repeat. Nature. 2012; 491:454-457.

131. Carrieri C, Forrest AR, Santoro C, Persichetti F, Carninci P, Zucchelli S, Gustincich S. Expression analysis of the long non-coding RNA antisense to Uchll (AS Uchl1) during dopaminergic cells' differentiation in vitro and in neurochemical models of Parkinson's disease. Front Cell Neurosci. 2015; 9:114.

132. Soreq L, Guffanti A, Salomonis N, Simchovitz A, Israel Z, Bergman H, Soreq H. Long non-coding RNA and alternative splicing modulations in Parkinson's leukocytes identified by RNA sequencing. PLoS Comput Biol. 2014; 10:e1003517.

133. Driscoll DJ, Miller JL, Schwartz S, Cassidy SB. PraderWilli Syndrome. In: Adam MP, Ardinger HH, Pagon RA, Wallace SE, Bean LJH, Mefford HC, Stephens K, Amemiya A, Ledbetter N, eds. GeneReviews(R). Seattle (WA). 1993.

134. Yin QF, Yang L, Zhang Y, Xiang JF, Wu YW, Carmichael GG, Chen LL. Long noncoding RNAs with snoRNA ends. Mol Cell. 2012; 48:219-230.

135. McCann KL, Baserga SJ. Long noncoding RNAs as sinks in Prader-Willi syndrome. Mol Cell. 2012; 48:155-157.

136. Pagliardini S, Ren J, Wevrick R, Greer JJ. Developmental abnormalities of neuronal structure and function in prenatal mice lacking the prader-willi syndrome gene necdin. Am J Pathol. 2005; 167:175-191.

137. O’Neill MA, Farooqi IS, Wevrick R. Evaluation of PraderWilli Syndrome gene MAGEL2 in severe childhood-onset obesity. Obes Res. 2005; 13:1841-1842.

138. Powell WT, Coulson RL, Crary FK, Wong SS, Ach RA, Tsang P, Alice Yamada N, Yasui DH, Lasalle JM. A PraderWilli locus lncRNA cloud modulates diurnal genes and energy expenditure. Hum Mol Genet. 2013; 22:4318-4328.

139. Wevrick R, Kerns JA, Francke U. Identification of a novel paternally expressed gene in the Prader-Willi syndrome region. Hum Mol Genet. 1994; 3:1877-1882.

140. Hassan M, Butler MG. Prader-Willi syndrome and atypical submicroscopic 15q11-q13 deletions with or without imprinting defects. Eur J Med Genet. 2016; 59:584-589.

141. Bassell GJ, Warren ST. Fragile X syndrome: loss of local mRNA regulation alters synaptic development and function. Neuron. 2008; 60:201-214.

142. Tang J, Yu Y, Yang W. Long noncoding RNA and its contribution to autism spectrum disorders. CNS Neurosci Ther. 2017; 23:645-656.

143. Peschansky VJ, Pastori C, Zeier Z, Motti D, Wentzel K, Velmeshev D, Magistri M, Bixby JL, Lemmon VP, Silva 
JP, Wahlestedt C. Changes in expression of the long noncoding RNA FMR4 associate with altered gene expression during differentiation of human neural precursor cells. Front Genet. 2015; 6:263.

144. Pastori C, Peschansky VJ, Barbouth D, Mehta A, Silva JP, Wahlestedt C. Comprehensive analysis of the transcriptional landscape of the human FMR1 gene reveals two new long noncoding RNAs differentially expressed in Fragile X syndrome and Fragile X-associated tremor/ataxia syndrome. Hum Genet. 2014; 133:59-67.

145. Massone S, Vassallo I, Fiorino G, Castelnuovo M, Barbieri F, Borghi R, Tabaton M, Robello M, Gatta E, Russo C, Florio T, Dieci G, Cancedda R, et al. 17A, a novel noncoding RNA, regulates GABA B alternative splicing and signaling in response to inflammatory stimuli and in Alzheimer disease. Neurobiol Dis. 2011; 41:308-317.

146. Massone S, Ciarlo E, Vella S, Nizzari M, Florio T, Russo C, Cancedda R, Pagano A. NDM29, a RNA polymerase III-dependent non coding RNA, promotes amyloidogenic processing of APP and amyloid beta secretion. Biochim Biophys Acta. 2012; 1823:1170-1177.

147. Iacoangeli A, Bianchi R, Tiedge H. Regulatory RNAs in brain function and disorders. Brain Res. 2010; 1338:36-47.

148. Parenti R, Paratore S, Torrisi A, Cavallaro S. A natural antisense transcript against Rad18, specifically expressed in neurons and upregulated during beta-amyloid-induced apoptosis. The European Journal of Neuroscience. 2007; 26:2444-2457.

149. Liu S, Cui B, Dai ZX, Shi PK, Wang ZH, Guo YY. Long Non-coding RNA HOTAIR Promotes Parkinson's Disease Induced by MPTP Through up-regulating the Expression of LRRK2. Curr Neurovasc Res. 2016; 13:115-120.

150. Korostowski L, Sedlak N, Engel N. The Kcnq1ot1 long non-coding RNA affects chromatin conformation and expression of Kcnq1, but does not regulate its imprinting in the developing heart. PLoS Genet. 2012; 8:e1002956.

151. Zhang X, Azhar G, Chai J, Sheridan P, Nagano K, Brown T, Yang J, Khrapko K, Borras AM, Lawitts J, Misra RP, Wei JY. Cardiomyopathy in transgenic mice with cardiacspecific overexpression of serum response factor. Am J Physiol Heart Circ Physiol. 2001; 280:H1782-1792.
152. Papait R, Kunderfranco P, Stirparo GG, Latronico MV, Condorelli G. Long noncoding RNA: a new player of heart failure? J Cardiovasc Transl Res. 2013; 6:876-883.

153. Leung A, Trac C, Jin W, Lanting L, Akbany A, Saetrom P, Schones DE, Natarajan R. Novel long noncoding RNAs are regulated by angiotensin II in vascular smooth muscle cells. Circulation Research. 2013; 113:266-278.

154. Zhu J, Zhu Z, Hu S, Yin L. Expression of lncRNA Novlnc6 in plasma and its clinical correlation with coronary artery disease. Biomedical Research. 2017; 28:7055-7059.

155. Zhou W, Ye XL, Xu J, Cao MG, Fang ZY, Li LY, Guan GH, Liu Q, Qian YH, Xie D. The lncRNA H19 mediates breast cancer cell plasticity during EMT and MET plasticity by differentially sponging miR-200b/c and let-7b. Sci Signal. $2017 ; 10$.

156. Huang YS, Chang CC, Lee SS, Jou YS, Shih HM. Xist reduction in breast cancer upregulates AKT phosphorylation via HDAC3-mediated repression of PHLPP1 expression. Oncotarget. 2016; 7:43256-43266. https://doi.org/10.18632/ oncotarget.9673.

157. Ounzain S, Pezzuto I, Micheletti R, Burdet F, Sheta R, Nemir M, Gonzales C, Sarre A, Alexanian M, Blow MJ, May D, Johnson R, Dauvillier J, et al. Functional importance of cardiac enhancer-associated noncoding RNAs in heart development and disease. J Mol Cell Cardiol. 2014; 76:55-70.

158. Arun G, Diermeier S, Akerman M, Chang KC, Wilkinson JE, Hearn S, Kim Y, MacLeod AR, Krainer AR, Norton L, Brogi E, Egeblad M, Spector DL. Differentiation of mammary tumors and reduction in metastasis upon Malat1 lncRNA loss. Genes \& Development. 2016; 30:34-51.

159. Jiang H, Hu X, Zhang H, Li W. Down-regulation of LncRNA TUG1 enhances radiosensitivity in bladder cancer via suppressing HMGB1 expression. Radiat Oncol. 2017; 12:65.

160. Li Z, Li X, Wu S, Xue M, Chen W. Long non-coding RNA UCA1 promotes glycolysis by upregulating hexokinase 2 through the mTOR-STAT3/microRNA143 pathway. Cancer Sci. 2014; 105:951-955. 